University of South Florida

DIGITAL COMMONS Digital Commons @ University of @ UNIVERSITY OF SOUTH FLORIDA South Florida

$1-1-2002$

\title{
Community Impact Assessment and Environmental Justice for Transit Agencies: A Reference
}

CUTR

Follow this and additional works at: https://digitalcommons.usf.edu/cutr_nctr

\section{Scholar Commons Citation}

CUTR, "Community Impact Assessment and Environmental Justice for Transit Agencies: A Reference" (2002). Research Reports. 220.

https://digitalcommons.usf.edu/cutr_nctr/220

This Technical Report is brought to you for free and open access by the National Center for Transit Research (NCTR) Archive (2000-2020) at Digital Commons @ University of South Florida. It has been accepted for inclusion in Research Reports by an authorized administrator of Digital Commons @ University of South Florida. For more information, please contact digitalcommons@usf.edu. 


\section{Community Impact Assessment and Environmental Justice}

for Transit Agencies: A Reference

Public Transit Office

Florida Department of Transportation

National Center for Transit Research

Center for Urban Transportation Research

University of South Florida

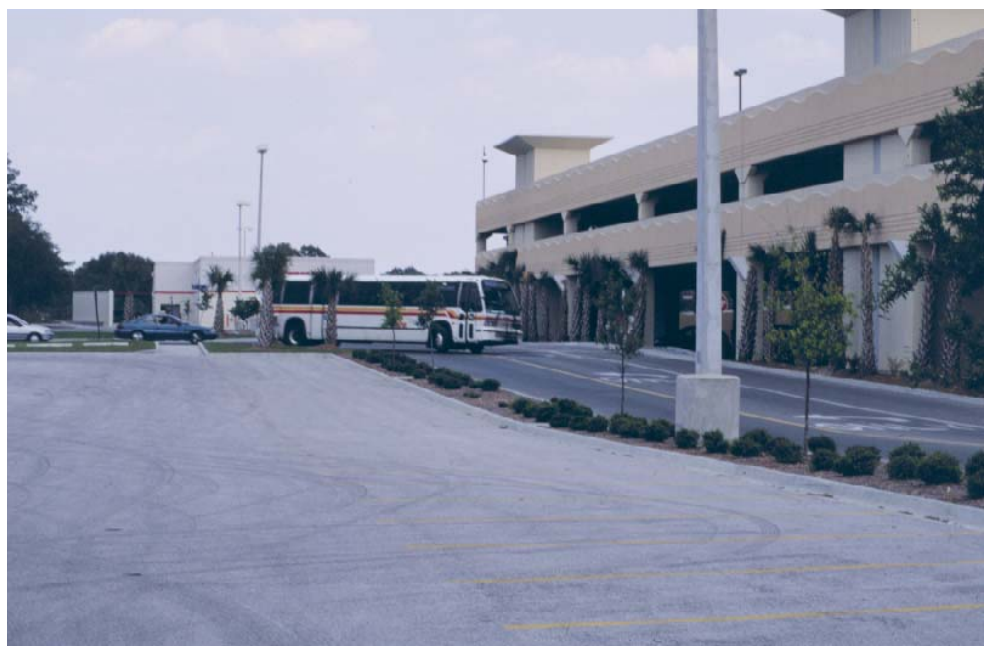




\section{DISCLAIMER}

The opinions, findings, and conclusions expressed in this publication are those of the author(s) who are responsible for the facts and accuracy of the data presented herein. The contents do not necessarily reflect the views or policies of the Florida Department of Transportation or the Research and Special Programs Administration. This report does not constitute a standard, specification, or regulation.

The report is prepared in cooperation with the State of Florida Department of Transportation and the U. S. Department of Transportation. 


\section{Community Impact Assessment and Environmental Justice for Transit Agencies: A Reference}

January 2002

Public Transit Office Florida Department of Transportation

National Center for Transit Research Center for Urban Transportation Research

University of South Florida 


\section{Objectives}

This guide was developed through a grant from the National Center for Transit Research and the Florida Department of Transportation, Public Transit Office. The objectives of the research included identifying information and materials on issues and resources related to environmental justice, Title VI of the Civil Rights Act of 1964, social equity, and the use of community impact assessment techniques (CIA) in the transit industry. As a result of the research and the primer, Community Impact Assessment: A Quick Reference Guide for

Transportation (hereinafter referred to as the CIA Reference), the purpose of this guide is to provide tools, techniques, and references that may be used to assess transit actions.

Although environmental justice and Title VI issues receive special attention, the emphasis is on the use of the impact assessment process for all communities. Many transportation professionals and analysts state that, if transportation actions are properly assessed, environmental justice, Title VI, and other social issues will be addressed and in a manner that allows the input of the public throughout the decision-making process.

\section{Recognition}

Special thanks to the following transit professionals for their assistance in the research:

Diana Carsey

Hillsborough Area Regional Transit (HARTline)

\section{Bill Carter}

Tallahassee Transit (Taltran)

Beth Coulliette

Bay County Council on Aging-Coordinated Transportation (BCCOA)

Ken Fischer

County of Volusia (VOTRAN) 
Peter Gajdjis

Manatee County Area Transit (MCAT)

\section{Steve Githens}

Lakeland Area Mass Transit District (LAMT)

Jay Goodwill

Sarasota County Area Transit (SCAT)

Robert Jacobson

Indian River County Council on Aging (IRRCOA)

Jim Liesenfelt

Space Coast Area Transit (SCAT)

Perry Maull

Palm Beach County Transportation Authority

(Palm Tran)

Patrice Rosemond

Miami-Dade Transit Agency (MDTA)
Maria Savoia

Regional Transit System (Gainesville)

Spencer Stoleson

Broward County Mass Transit Division

Roger Sweeney

Pinellas Suncoast Transit Authority (PSTA)

Tony Walter

LYNX (Central Florida Regional Transportation Authority)

Michael Williams

Tri-County Commuter Rail Authority (Tri-Rail)

Nedra Woodyatt

Escambia County Area Transit (ECAT) 


\section{Introduction}

Over the last decade, a renewed focus on the impacts of transportation actions on communities has been witnessed throughout the industry. The impetus has been multifaceted, sometimes led by citizens or "grassroots" organizations, the result of adverse impacts; or proactive legislation and guidance from public agencies.

Much of the early guidance on how to assess impacts focused on the National Environmental Policy Act (NEPA) of 1969 process, specifically project development. As the public and practitioners have gained a better understanding of the social effects of transportation actions, the need to include the public early on in and throughout the assessment process has been recognized. Further, in the case of transit agencies, the impacts of many proposed actions are not subject to the project development process, but should be assessed due to the use of federal funds.

The Federal Transit Administration (FTA) Office of Planning (TPL) states in resource in- formation on social impacts, "Transit projects affect the social environment in several ways and may change the physical layout, demographics and sense of neighborhood in local communities." Working together, transit planners and communities can avoid, mitigate, or minimize these impacts, and enhance communities.

\section{Community Impact Assessment}

"Community impact assessment [CIA] is a process to evaluate the effects of a transportation action on a community and its quality of life" (FHWA, Apogee, and Parsons,

Brinckerhoff, Quade, and Douglas 1996:4). It is a way to incorporate community considerations into transportation decision-making. From a policy perspective, it is a process for assessing the social and economic impacts of transportation projects as required by the NEPA, Title VI, and other legislation. The assessment may address a variety of important community issues and relies on public involvement as a major tool for data collection. 
Since the early 1990s, federal and state transportation agencies have refocused efforts to involve communities when considering transportation actions in order to assess the social impacts of the proposed actions. These efforts have included greater public involvement; training, regulations, handbooks, and other guidance for transportation professionals; and the compilation of a number of techniques and tools commonly identified as the community impact assessment process. This increased emphasis on the human environment was first prompted by the Intermodal Surface

Transportation Efficiency Act (ISTEA) of 1991, specifically its revitalization of public involvement. ISTEA provided a systematic method for "... setting up and implementing a public involvement program for a specific plan, program, or project" (US DOT 1996:11). The 1994 EO12898, as discussed above, and the subsequent orders fueled these efforts. TEA-21, the successor to ISTEA, continues the strong emphasis on public involvement and extends the commitment to consideration of community impacts.

In May 2000, the FHWA issued a Notice of Proposed Rule Making intended to coordinate and streamline planning and project development as defined in the NEPA process. The proposed rule states that it is a requirement to coordinate and streamline the planning and NEPA process. The rule further requires integration of community impact assessment activities in the transportation planning process and increased coordination of the planning and project development processes.
Assessing Title VI Capability-Federal Transit Administration (FTA)/FHWA

Actions Environmental Justice in State Planning and Research (SPR) and Unified Planning Work Programs (UPWPs)

At a minimum, FHWA and FTA should review with States, MPOs, and transit operators how Title VI is addressed as part of their public involvement and plan development processes. Since there is likely to be the need for some upgrading of activity in this area, a work element to assess and develop improved strategies for reaching minority and low-income groups through public involvement efforts and to begin developing or enhancing analytical capability for assessing impact distributions should be considered [emphasis added] in upcoming SPRs and UPWPs.

Federal Register: May 19, 2000 65(98) 
Also in May 2000, FHWA published in the Federal Register "Policy Guidance Concerning Application of Title VI of the Civil Rights Act of 1964 to Metropolitan and Statewide Planning." (The guidance was first issued in October 1999 as a joint memorandum from the FHWA and

FTA.) Of particular interest to transit agencies is the review by FHWA and FTA on how transit operators address Title VI and the agencies' impact assessment capabilities.

\section{Environmental Justice}

The Executive Order (EO) 12898, Federal Actions to Address Environmental Justice in Minority Populations and Low-Income Populations, issued on February 11, 1994, required each Federal agency to develop an agencywide environmental justice strategy. The EO has as its main purpose the reinforcement of existing environmental and civil rights legislation to ensure that low-income and minority populations are not subject to disproportionately high and adverse environmental effects. The Environmental Protection Agency's (EPA) Office of
Environmental Justice offers the following definition of environmental justice:

The fair treatment and meaningful involvement of all people regardless of race, color, national origin, or income with respect to the development, implementation, and enforcement of environmental laws, regulations, and policies. Fair treatment means that no group of people, including racial, ethnic, or socioeconomic group, should bear a disproportionate share of the negative environmental consequences resulting from industrial, municipal, and commercial operations or the execution of federal, state, local, and tribal programs and policies (Office of Enforcement and Compliance Assurance 2000).

There is a school of thought that "environmental justice is a discipline that focuses on the recognition and mitigation of such discrepancies [i.e., disparate impacts of transportation 
planning and development]."

Forkenbrock and

Schweitzer state,

however, that "environmental justice

represents a public

policy goal of ensuring that adverse

human health or en-

vironmental effects of

government activities do not fall disproportionately upon

minority or low-income populations"

(Forkenbrock 1997:1).

The EO builds upon the directives outlined in the Title VI, the National Environmental Policy Act of 1969, and the Clean Air Act as amended, all of for

\section{UMTA (now known as FTA ) Circular 4702.1, May 26, 1988, in part}

\section{CHAPTER I}

2. The objectives of the [FTA] Title VI program are as follows:

a. To ensure that UMTA-assisted benefits and related services are made available and are equitably distributed without regard to race, color, or national origin;

b. To ensure that the level and quality of UMTA-assisted transit services are sufficient to provide equal access and mobility for any person without regard to race, color, or national origin;

c. To ensure that opportunities to participate in the transit planning and decisionmaking processes were provided to persons without regard to race, color, or national origin;

d. To ensure that decisions on the location of transit services and facilities are made without regard to race, color, or national origin; and

e. To ensure that corrective and remedial action is taken by all applicants and recipients of UMTA assistance to prevent discriminatory treatment of any beneficiary based on race, color, or national origin.

These objectives are the basis for the implementation of the [FTA] Title VI program. Applicants, recipients, and subrecipients of [FTA] financial assistance must adopt a Title VI compliance program that is consistent with the requirements in this circular. 
which are strongly linked to the Transportation Equity Act for the $21^{\text {st }}$ Century (TEA-21). The United States Department of Transportation (US DOT) subsequently set a goal to become a model agency for protecting and enhancing the environment and quality of life of U.S. citizens and issued a departmental order on environmental justice in 1997. The Federal Highway Administration (FHWA) issued a related administrative order in 1998.

Ethnic or racial minority and low-income population groups appear to experience differences in disease and death rates; however, the data explaining the environmental contributions to these differences are limited.

Information normally is not collected on environmental health effects by race and income. Nor is it collected on health risks posed by multiple industrial facilities or transportation facilities. For diseases known to have environmental causes, data are not typically disaggregated by race and socioeconomic group. The literature suggests that racial minority and low-income populations experience higher than average exposures to selected air pollutants and hazardous waste facilities. This exposure does not always lead to serious health problems, but is cause for health concerns.

Beyond environmental justice, all the human and environment assessment issues are based on legislation and regulations that direct evaluation in transportation decision-making, planning, project development, and subsequent processes. These directives relate to economic, social, and environmental effects. The topics fall into several areas: community cohesion; environmental impact assessment; environmental justice; landuse planning; and socioeconomic impacts.

Finally, consideration of these issues relates to the distribution of and access to resources - power differentials. Manheim states,

An essential characteristic of transportation is the differential incidence of its impacts. Some groups will gain from any transportation change; others may lose. Therefore, transportation choices are 
essentially sociopolitical choices: the interests of different groups must be balanced (1979:19).

The sociopolitical choices of past transportation actions, particularly as related to the interstate highway system, have disproportionately affected low-income or minority ethnic communities. As early as 1970, Helen Leavitt documented the disruption of black communities by superhighway plans (in passim: 1970). In Divided Highways, Tom Lewis also documents several African American communities displaced by the interstates (Lewis 1997:186-89, 197, 199). More recently, grassroots organizations have begun to challenge transportation investments. For example, in roadway investments versus pedestrian and bicycle facilities, African Americans and other people of color walk, bicycle, and use transit more than their white counterparts, but are more likely to be victims of automobile-pedestrian or -bicycle crashes than the average person (Corless and Arteaga 2000:8). Grassroots organizations also have been successful in challenging expenditures

\section{Legal Basis}

There are several Federal regulations, statutes, policies, and orders that require assessment of the social impacts of transportation actions. Many of the legal requirements relate to all federally assisted projects. Others, however, place specific requirements on recipients of funds from FTA.

EO 12898 Federal Actions to Address Environmental Justice in Minority Populations and Low-income Populations

EO 13166 Improving Access to Services for Persons with Limited English Proficiency

FHWA (Administrative Order) 6640.23 Actions to Address Environmental Justice in Minority Populations and Low-income Populations

FHWA/FTA Memorandum on Title VI Requirements in Metropolitan and Statewide Planning

Florida Administrative Code (FAC) Chapter 14-73

(continued) 


\section{Legal Basis (continued)}

Florida Statute $\$ 341.052$

NEPA of 1969

"Nondiscrimination in Federally-Assisted Programs of the Department of Transportation - Effectuation of Title VI of the Civil Rights Act," 49 C.F.R. Part 21

Office of the Secretary of the Department of Transportation (OST) Docket No. 50125 Department of Transportation Order to Address Environmental Justice in Minority Populations and LowIncome Populations

Title VI of the Civil Rights Act of 1964, as amended, and related statutes

Transportation Equity Act for the $21^{\text {st }}$ Century

UMTA (FTA) Circular 4702.1, Title VI Program Guidelines for Federal Transit Administration Recipients, 26 May 1988 light rail versus rubber tire transit in Atlanta and Los Angeles (Bullard 2000:4; Garcia 2000:10). As one of the leading researchers on transportation and environmental justice stated, "Transportation is not just law. It is politics and community." (Oedel 2000:10). 


\section{The Assessment Process}

The CIA process is holistic and iterative, beginning with the conception of an action through implementation, monitoring, and evaluation. Public involvement is an integral tool. The basic steps of the process are listed below:

Step 1. Determine the nature of the action and define the study area.

Step 2. Develop a community profile to gain a thorough understanding of the study area, including any issues surrounding the proposed action. This information provides a baseline for analysis and is used to understand what would happen in the community with and without the action.

Step 3. Analyze each alternative identified and identify any potential impacts and the magnitude of those potential impacts. Identify

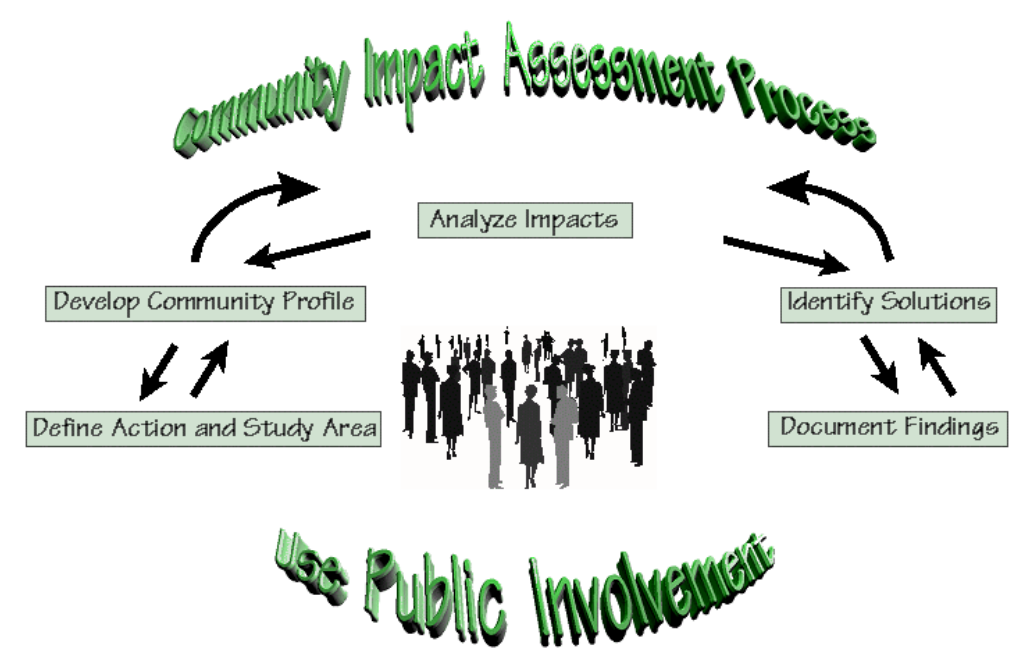

Figure 1. The Community Impact Assessment Process

which group or groups may be impacted.

Step 4. Identify potential solutions to adverse impacts.

Step 5. Document the findings, including impacts, solutions, and commitments. 
For transit agencies, many of the above steps and the techniques discussed below are similar to the data collection and reporting requirements and monitoring procedures for the Title VI Program for FTA recipients. The assessment process described, however, provides the opportunity to enhance the agencies' assessment capabilities for all communities and its holistic approach fully incorporates Title VI and environmental justice issues into decisionmaking.

\section{Overview of the Remainder of the Reference}

The remainder of the reference provides information on how the assessment process can be used to address transit actions. The next section, Transit Service Area Profile, combines the development of a community profile with the demographic and service profile and other data collection requirements of UMTA (FTA) Circular 4702.1. The analysis of community facilities and services, population characteristics, and other socioeconomic con- siderations are the basis of the assessment process.

The following section presents examples of possible transportation actions and their potential impacts on communities. These examples are discussed in the context of community cohesion, safety, Titles VI and VIII of the Civil Rights Act of 1964, environmental justice, landuse, mobility and travel patterns, aesthetics and visual qualities, consistency with local, regional, and state plans, and cumulative and secondary impacts.

Undergirding the assessment process is the use of public involvement and outreach, particularly to underrepresented segments of the public.

The final section is resources, including references, websites, contacts, and so forth. 
The FTA TPL in its resource information on the environmental process states the regulations implementing NEPA "...ensure that information on the social and environmental impacts of any federally-funded action is available to public officials and citizens before decisions are made and before actions are taken [emphasis original]." FTA also uses the NEPA process as an "overarching umbrella" to consider other provisions, including civil rights and other social impacts, that affect decision-making. This may include such actions as:

- changes in geographic areas of service;

- travel times and reliability;

- frequency and hours of service;

- changes in transit patronage and demand;

- $\quad$ changes in transit mode;

- changes in station access and circulation; and

- increased traffic around stations and depots.

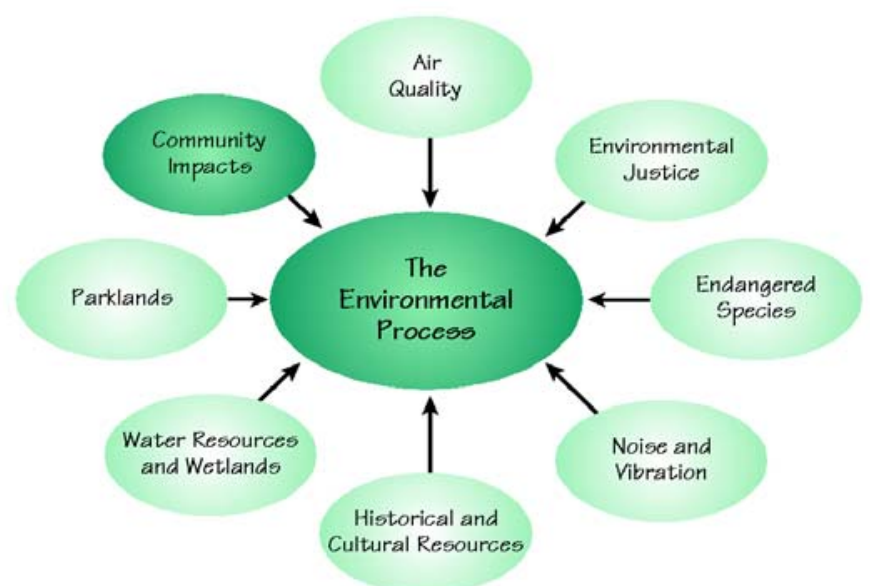

Figure 2. Community impacts in relation to other environmental issues

\section{Defining the Action}

Step 1 of the community impact assessment process described above is "Determine the nature of the [proposed] action and define the study area." This project identification process generally has been associated with the project development and environment (PD\&E) phase of 
roadway or other construction projects. It is used to determine the purpose and need of the project and develop project alternatives as required by NEPA. In planning, this process is similar to problem definition.

Inclusion of community analysts, resource agencies, and the public in this initial phase, however, provides the opportunity for new perspectives on the proposed action. In addition, issues or concerns of the community are raised before major investments in staff, time, and other resources are committed to particular alternatives. Early and continuous public involvement is central to community impact assessment.

\section{Using Title VI Demographic and}

Service Profile Maps, Overlays, and Charts

As discussed earlier, proposed transportation actions are associated with a geographic area within the service area or a proposed increase to the service area. Transit may have an advantage over other transportation agencies due to the development of maps and overlays compiled as part of their program guidelines. These maps and overlays may be provide baseline data for a more comprehensive analysis of any impacts. The benefits of the assessment process include:

- providing the opportunity for consideration of environmental justice and Title VI issues on each proposed action by allowing input from low-income and minority communities;
- providing the opportunity for all affected communities, whether lowincome, minority, or not, on each proposed action;

- facilitating interagency coordination by identifying these stakeholderers and seeking their input; and

- providing a proactive and collaborative approach to problem-solving.

The Title VI Demographic and Service Profile Map is a base map providing general information on the population and key facilities in the service area. As service changes are suggested, this base map is the starting point for more intensive analysis around a smaller study area.

Florida Statute $\$ 341.052$ requires eligible recipients of public transit block grant funds to

...establish public transportation development plans consistent, to the 


\section{FTA Circular 4702.1, in part \\ CHAPTER III}

\section{DATA COLLECTION AND REPORTING REQUIREMENTS}

3(1)(1) Demographic and Service Profile Maps, Overlays and Charts. The [Department of Justice] DOJ and [Department of Transportation] DOT regulations state that Federal agencies should require information on the minority population eligible to receive federally funded services. To address this requirement, FTA requires transit providers meeting the threshold to prepare the following demographic and service profile maps, overlays, and charts....

1. Base Map. A legible scaled map of the transit service area which identifies:

a Each census tract by number or traffic analysis zone;

$\underline{b}$ Major streets and highways;

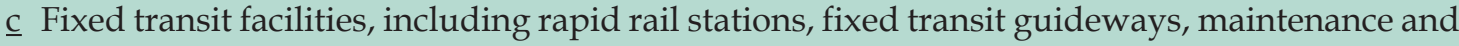
garage facilities, and administrative buildings; and

d Major activity centers or transit trip generators, such as the central business district, outlying high employment areas, schools, and hospitals.

2. Overlays. Two transparencies must be submitted which show the distribution of the minority population and transit service in the service area....

a Minority Population Overlay. This overlay should encompass the entire service zone, showing the total minority population for each census tract or traffic analysis zone shown on the base map 


\section{FTA Circular 4702.1, in part \\ CHAPTER III \\ DATA COLLECTION AND REPORTING REQUIREMENTS (continued)}

expressed in raw numbers and as a percentage for that tract or zone....

b Transit Service Overlay. This overlay should show all transit routes, including rail lines in the service area, with their origins and destinations. The type(s) of service provided on each route should be indicated (e.g., express, limited, local, or commuter service) as well as, the time of service (e.g., peak hour only; non-peak hour all day service).

3. Population/Racial Distribution Chart. ...FTA requires a chart for each census tract or traffic analysis zone showing the actual numbers and percent ages for each minority group within that zone or tracts. The total population should also be shown.

A summary chart...should be prepared for the entire service area. maximum extent feasible, with approved local government comprehensive plans of the units of local government in which the provider is located.

Current legislation mandates that providers provide information to regional workforce boards servicing their counties regarding the availability of transportation services for persons in welfare transition programs. The transportation development plan (TDP), with its annual updates, is the primary "action" undertaken by Florida public transportation providers. The reference to persons in the welfare transition program heightens the need to consider the effects of the plan on low-income communities. The community impact assessment process can provide a complementary set of tools to the TDP, helping to meet the requirements of the Florida Administrative Code (FAC).

The FAC provides the rules and regulations for completing the TDP. The basic elements of the TDP include: 
- community goals and policies;

- demographic, socioeconomic, land use, transportation, and transit data;

- public involvement;

- public and private transit service analysis; and

- a five-year implementation program for selected alternatives.

The TDP can be an extensive data collection and analysis undertaking, especially for first-time applicants. Some transit agencies have in-house staff prepare the TDP, others use outside consultants. Much of the information, however, is available through other resource agencies in the community or via the Internet. Resource agencies and the public are the primary sources for community values, issues, and needs and serve to verify data collected from other sources.

The CIA Reference describes the study area as communities within and immediately surrounding where the proposed change will occur. This area may change due to impacts to other communities that are identified later. This is an iterative process.

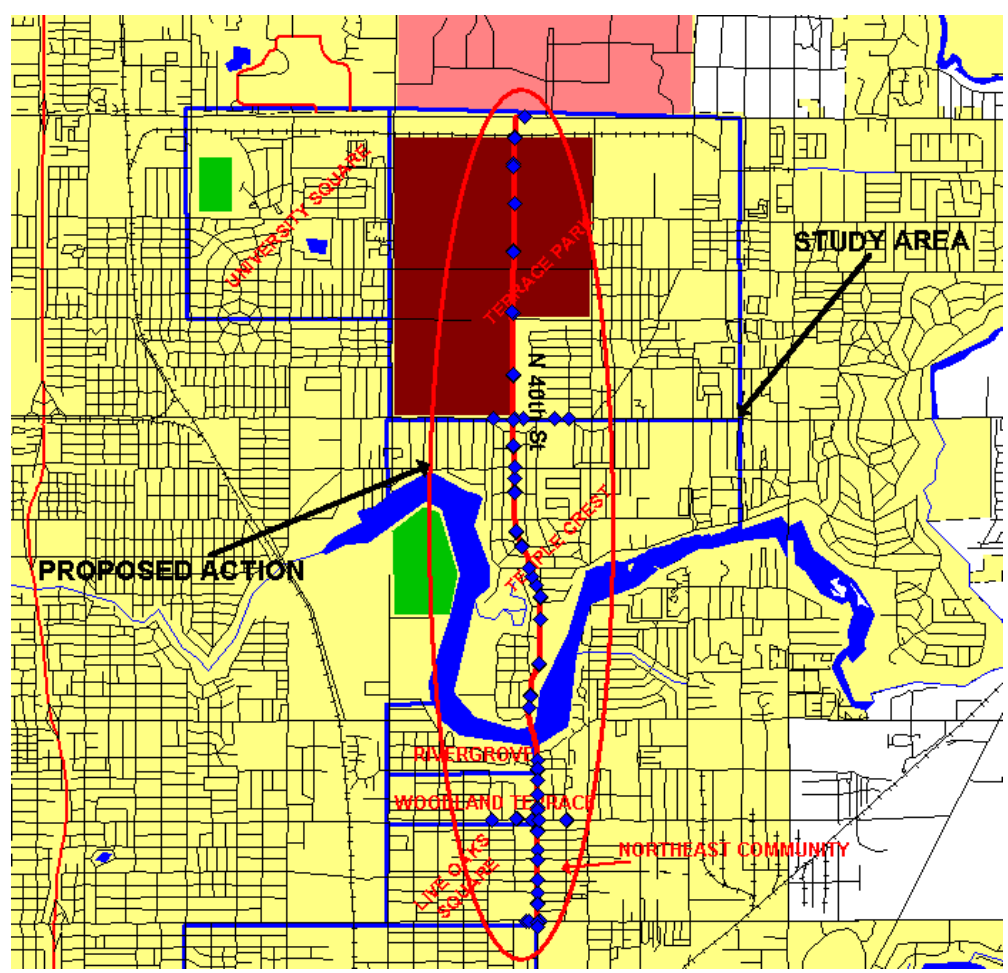

Figure 3. Study area, proposed action, bus route with bus stops, and communties

Transit Service Area Profile 


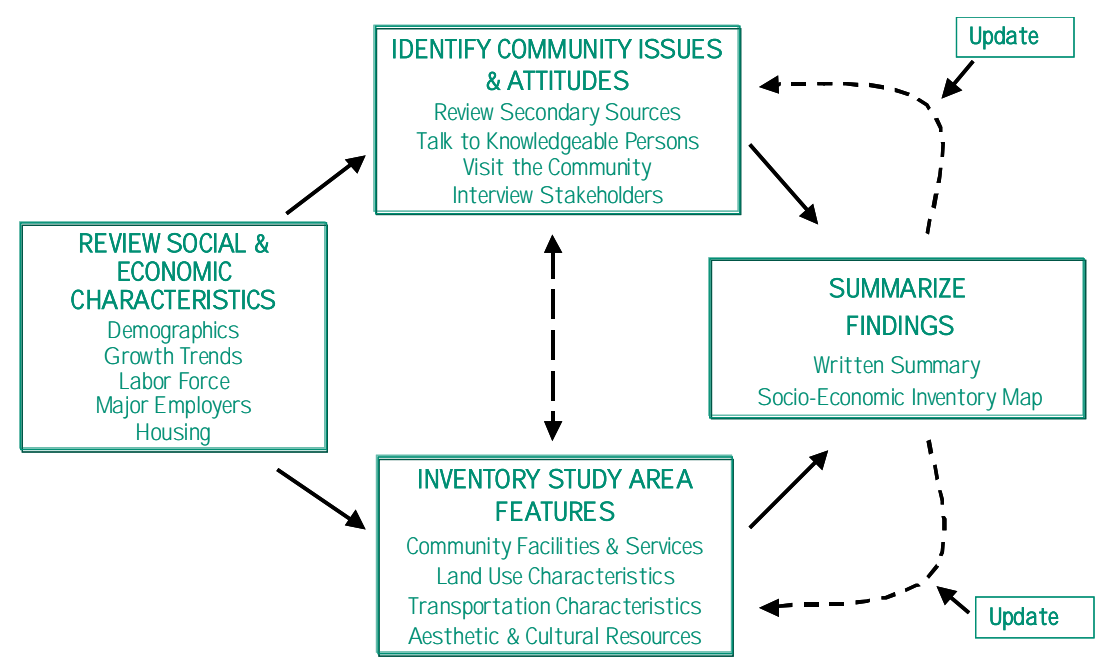

Figure 4. Developing a Community Profile

\section{The Community Profile}

More and more agencies are using geographic information systems to develop Title VI maps and for other purposes, either through in-house systems or online resources. This base map provides a bird's eye view of conditions in the service area and is an integral part of developing a community profile. Williams et al. state,

The community profile is a summary of baseline conditions and trends in a community and study area. It establishes the context for assessing potential impacts and for... . decisionmaking. Developing a community profile involves identifying community issues and attitudes, locating notable features in the study area, and assessing social and economic conditions and trends in the community and region that have a bearing on the transportation action (2000).

The baseline map, as shown in Figure 3, provides a visual presentation of the study area characteristics. Other elements of the community profile may include a narrative description of the area, with emphasis on community characteristics, demographics, history, and important facilities. Other graphics, 
such as photographs, charts, and tables also may be presented.

The CIA Reference provides the following guidance on developing a community profile:

- define community boundaries, and neighborhood or subdivision boundaries;

- locate businesses, residences, and activity centers of potentialimpact, especially neighborhoods along highway alternatives and near interchanges;

- determine demographic characterististics, economic base, location of community facilities, and other characteristics;

- learn about a community within the study area by comparing local or area population demographics, land-use, and other characteristics with State or regional information; and

- continually refine the profile through out the assessment process as impacts are identified and as situations change over time (1996).
The community profile provides information on the "affected environment" in NEPA documentation. To complete the profile several types of data are collected and summarized. The data collection effort and the level of documentation varies according to the proposed action. Examples of the types of data include population and demographic characteristics; economic and social history and characteristics; and physical characteristics that are related to community activities.

\section{Socioeconomic Data Collection}

As discussed earlier, transit agencies may have advantages, since a considerable amount of archival data may be available in-house from development of the Title VI Demographic and Service Profile Maps. With additional data sources, particularly public involvement, these data can be supplemented to assess the impacts of any action for any community.

Federal, State, and local governments are good sources of archival data. Planning agencies can provide demographic and economic information for a city, county, or region. This information also may be summarized in local comprehensive plans and metropolitan planning organization (MPO) long range plans. The U.S. Census also provides much of this information. Demographic information is also regularly compiled and maintained by other agencies such as school districts, human service agencies, water management districts, and health departments. Increasingly, more of this data is available on the Internet. 


\section{Types of Data}

\section{Demographic}

Population and growth trends

Age distribution

Average household size

Ethnic composition

Average household income (compare to surrounding area)

Concentrations of special groups

Children five years of age and younger

Elderly persons

Minority or low-income populations

Persons with disabilities

Religious or ethnic groups

\section{Economic characteristics}

Unemployment rates and trends

Workforce characterization (SIC codes)

Dominant business sector type

Major employers

\section{Housing}

Age, type, and condition of structures

Vacancy rates and trends

Length of residency (percentage of residents five years or more)

Extent and availability of low-income housing

Types of residences

Rental units

Homeowners
Representatives of these agencies also are good resource persons who may be interviewed or otherwise participate in the assessment process.

\section{Inventory Com- munity Facilities and Resources}

A compilation of facilities, services, and other resources in the study area is part of the data collection effort.

Depending on the extent of the proposed action, these resources may be added to the base 
map. These data are useful in determining impacts of the proposed action to needed services. Although the inventory begins during initial data collection, it should be updated and expanded as the assessment proceeds. The inventory builds on data that should already be available from the Title VIService Map. It may include the following:

- Medical and health care facilities

\section{Data}

\section{Sources}

Aerial and road maps

Census Bureau and statistical abstracts

City, Donnelley, or Yellow Pages directories and Dun and Bradstreet (D\&B) databases

Field surveys and reviews

Interviews and public involvement with business owners and community leaders and residents

Metropolitan Planning Organization (MPO)

Historical societies and State Historic Preservation Officer (SHPO)

Real estate journals and interviews

State and local government and social service agencies (including employment service and workforce board)

State, local, and university libraries Other important agencies, e.g., American Automobile Association, American Association of Retired Persons, chambers of commerce, congregate meal sites, religious institutions, etc.

\section{Typical Uses}

Community boundaries, physical characteristics, activity centers, facilities, businesses, and services

Population, demographics, socioeconomic indicators, and housing

Businesses and community facility locations and types

Location of structures and activity patterns

Community values, issues, and needs

Economic base, land use, long range plans

Historical background, location of historic structures, and districts

Housing prices, characteristics of structures, and neighborhood composition

Comprehensive plans, human service and other programs, and other general information

General information, historical background, and socioeconomic information Special populations and needs and issues of underrepresented communities 


\section{Community Profile Elements}

\section{Baseline Conditions}

Social Characteristics

Demographic Profile \& Special Populations

Community Issues and Attitudes

Community Facilities and Services

Community Cohesion

Mobility

Safety

Economic Characteristics

Labor Force Characteristics

Major Employers and Industries

Land-use and Transportation

Facilities

Existing and Planned Land Use

Existing Zoning

Growth Trends and Issues (past and present)

Notable Features in Study Area

Aesthetic Character

Historic Resources

Socioeconomic Baseline Map
- Educational facilities

- Religious institutions

- Public works and services

- Civic centers

- Recreational facilities

- Aesthetic, cultural, and historical resources

- Commercial facilities

- Land-use characteristics and transportation facilities.

\section{Community Issues and Attitudes}

Again, public involvement is essential to community impact assessment. Baseline socioeconomic data is part of a continuum in the assessment process. This data is supplemented by input from the affected communities. The data can be used to identify potential impacts, stakeholders, and key persons or groups. Several methods may be used to collect these data. Archival data or secondary source materials may provide insight into community issues. These sources include local government comprehensive plans, local policy studies, media reports, editorials, minutes of public hearings or meetings, published local histories, government reports, photographs of the area, or other documents. Other sources include: 
- interviewing key individuals;

- conducting community site visits to observe how facilities are used;

- interviewing stakeholders, those who may be directly affected by the action.

\section{Document Key Findings}

A summary document of key findings should be prepared, including a representative map. This document focuses on issues relevant to the proposed action. The map may provide relevant overlays of key population groups, neighborhoods, facilities, and other notable features. The map later may be used to compare alternatives to potential impacts and to inform the community and agency staff of the trade-offs among alternatives. The community profile document is a record of initial findings that is updated throughout the assessment. It may be included in NEPA documentation or used as a stand-alone document. 


\section{Florida Administrative Code (FAC) Chapter 14-73 Public Transportation, in part}

14-73.001 (6)(c)2. b. State Public Transit Block Grant funding requires the applicant to develop and adopt a Transit Development Plan (TDP)...A TDP shall comply with the following elements at a minimum.

I. The TDP shall identify and list community goals and policies with respect to transportation and land use in general and specifically to transit service.

II. The TDP shall identify and quantify the community's need for transit service using demographic, socioeconomic, land use, transportation, and transit data as appropriate. There shall be an opportunity for the public to express the need for transit service improvements, such as but not limited to, Citizens Advisory Committees and workshops.

III. The TDP shall include an analysis of the services currently provided in the community by public and private transit service providers in terms of quality and quantity of service...The process for selecting an alternative for implementation shall include an opportunity for public participation....

V. The TDP shall not be in conflict with the approved local government comprehensive plan and the comprehensive (long range) transportation plan....

\section{Actions and Impacts}

The initial community profile document, including the baseline data, provides a starting point for the analysis of the effects the proposed action on the community. Throughout data collection, review, and summary, community issues and needs are identified. In the process of evaluating existing transit services and developing alternatives, the effects of the alternatives or "actions" also must be evaluated. The CIA Reference suggests these guidelines:

- Keep community goals in mind when identifying impacts.

- Be cognizant of both positive and negative impacts.

- Consider both temporary and longterm impacts as well as secondary and cumulative effects.

- Focus on the magnitude of an issue or controversy, as it determines the level of specificity needed to address the issue. 
- Recognize the public's perception of impacts. If the public identifies issues, then review and address these issues.

\section{Interconnection of Impacts}

The above list of impacts is not exhaustive, nor do impacts occur in isolation. Different impacts may relate to each other. Impacts also may be direct, indirect, or cumulative, or the effects counterbalancing. Direct impacts generally have immediate or primary effects, such as relocation of residents or businesses or loss of access. Indirect impacts may be inadvertent or extend beyond the physical location of the action. Cumulative impacts may result when an action is considered in light of other actions that taken individually have different implications than when considered together. Effects of an action also may be counterbalancing, both beneficial and adverse. For example, siting a transfer terminal in a community may increase mobility for residents in surrounding neighborhoods, but also may increase traffic, noise, and other adverse impacts.

\section{Civil Rights and Environmental Justice}

Central to civil rights and environmental justice concerns is that the proposed action does not result in disproportionately high or adverse impacts, particularly to low-income or minority groups. The effects of the proposed action, beneficial and adverse, should be equitably distributed, in a nondiscriminatory manner. To assure equity in the process, efforts should be made to ensure that affected communities have access to the decisionmaking process, decisionmakers, and information. Special efforts may be necessary to include underrepresented groups, such as persons with disabilities, and persons unfamiliar with the democratic process, such as recent immigrants or persons who have historically not participated in the process.

Executive Order 12898 specifically addresses disproportionately high and adverse impacts on low-income and minority communities. Unfortunately, such impacts tend to occur as a result of cumulative or indirect impacts. That is, overtime, low-income or minority communities may experience the effects
(Continued on page 28.) 
Possible Impacts

\begin{tabular}{|c|c|}
\hline $\begin{array}{l}\quad \begin{array}{l}\text { Access and } \\
\text { Mobility }\end{array} \\
\text { Nonmotorized } \\
\text { Access } \\
\text { What effect will the } \\
\text { action have on } \\
\text { bicyclists' and } \\
\text { pedestrians' access } \\
\text { to facilities? } \\
\text { General } \\
\text { Multimodalism } \\
\text { How does the } \\
\text { action affect access } \\
\text { to other modes of } \\
\text { transportation? }\end{array}$ & $\begin{array}{l}\text { Displacement } \\
\text { Business Displace- } \\
\text { ments } \\
\text { Does the action } \\
\text { require displace- } \\
\text { ment of businesses, } \\
\text { religious institu- } \\
\text { tions, or other } \\
\text { special landuse? } \\
\text { Do the businesses } \\
\text { or institutions } \\
\text { have characteris- } \\
\text { tics unique to the } \\
\text { community? } \\
\text { Neighborhoods } \\
\text { What are the } \\
\text { effects on the } \\
\text { neighborhoods? }\end{array}$ \\
\hline
\end{tabular}

Relocation
Are relocation
sites available?
Residents
Will the action
require displace-
ment of residents?
What types of
residential units
are affected? Are
any residents
from special
population
groups, e.g.,
elderly, low-
income, persons
with disabilities?

\section{Economic}

Employment

Will the proposed action improve access to employment centers?

\section{Business}

Will the proposed action affect business access, activity, or visibility?

\section{Property values}

Will the proposed action affect property values, i.e, relocations, changes in land use?

\section{Tax base}

Will the proposed action affect the tax base, e.g., changes in property values, changes in activity, removal of taxable property from the base?

\section{Land-use}

\section{Compatibility with}

\section{Goals}

Is the action

consistent with the local plans? The community's goals?

26 Environmental Justice and Community Impact Assessment for Transit Agencies: A Reference 
Possible Impacts (continued)

Physical Intrusions
Barriers
Will the action
create a barrier
such as from walls
or fencing?
Sounds
Will the action
increase noise or
vibrations?
Other intrusions
Will the action
increase dust or
odors? Will it
decrease visibility?
Create a shadow-
ing effect on
property?

Public Services
Use of Public
Facilities
Will the action
increase access to
public facilities
(e.g., schools,
recreation
facilities, etc.)?
Compatibility
with Plans
Is the proposed
action consistent
with local plans
and zoning?

Safety
Pedestrians and
Bicyclists
How will the
proposed action
affect the safety of
nonmotorists?
Emergency
Response
Will the proposed
action affect the
response time of
emergency
workers (e.g., fire,
police, medical,
etc.)?

Social
Community
Cohesion
Will the action
affect interaction
among persons
and groups? Will
it change social
relationships and
patterns?
Isolation
Will groups of
people be sepa-
rated from others?
Population
Changes
Will the proposed
action cause
redistribution?

Quality of Life

How will the action affect the quality of life?

\section{Values}

Will the action cause a change in social values?

\section{Visual}

Aesthetics

How will the action affect the community's character? What are potential aesthetic effects? 


\section{Civil Rights and Related Legislation}

EO 12898 Federal Actions to Address Environmental Justice in Minority Populations and Low-income Populations

FHWA (Administrative Order) 6640.23 Actions to Address Environmental Justice in Minority Populations and Low-income Populations

FHWA/FTA Memorandum on Title VI Requirements in Metropolitan and Statewide Planning

"Nondiscrimination in Federally-Assisted Programs of the Department of Transportation Effectuation of Title VI of the Civil Rights Act," 49 C.F.R. Part 21

Office of the Secretary of the Department of Transportation (OST) Docket No. 50125 Department of Transportation Order to Address Environmental Justice in Minority Populations and Low-Income Populations

Title VI of the Civil Rights Act of 1964, as amended, and related statutes

UMTA (FTA) Circular 4702.1, Title VI Program Guidelines for Federal Transit Administration Recipients, 26 May 1988 of adverse impacts brought about by the actions of one or more agencies. While the community profile may help to identify such actions, public involvement and other community impact assessment techniques will help to assure identification of these effects with the help of the affected communities.

Assessment Tools

The CIA Reference states that there are several approaches 
to analyze impacts. The primary three discussed in the primer are comprehensive, comparative, and incremental. When evaluating impacts comprehensively, as much data as possible is collected, analyzed, and a determination is made. In general, comparative analyses are based on evaluations of similarities and differences between the proposed action and previous actions. Incremental evaluations build on data overtime until a determination can be made. The primer recommends that when using any approach to consider effects with and without the proposed action.

\section{Selected Tools}

Florida transit agency representatives indicated in a survey that a number of techniques are used to analyze the impacts of their

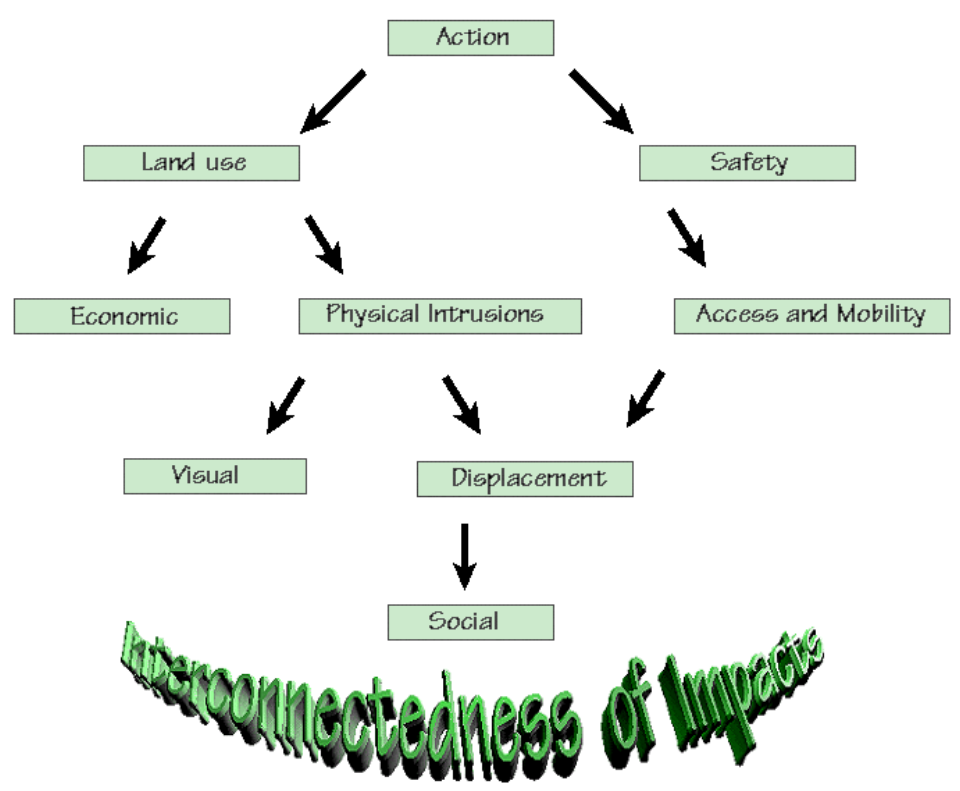

Figure 5. How impacts may interconnect 
actions. The following techniques or tools are listed in order of frequency of responses:

1. Public Involvement

2. Brainstorming

3. Comparisons

4. Statistical Analysis

5. Expert Consultation

6. Peer Reviews

7. Market Research

8. GIS/Databanks

9. Internet/World Wide Web

10. Map Overlays

11. Delphi Techniques

Several techniques may be combined to gain a better understanding of the community's concerns or to assure that different groups in the community are reached. The emphasis is not on a particular technique, but rather the involvement of the community in identifying impacts.

\section{Public Involvement}

As stated earlier, public involvement undergirds the CIA process. The CIA Reference states that the public can participate as follows:

- Development of the action's purpose and need and identification of alternatives.

- Development of the community profile.

- Identification and analysis of impacts.

- Identification of avoidance, minimization, mitigation, and enhancement opportunities.

The principles of public involvement in the community impact accessment process include early and continuous communication between affected communities and the proposing agency. The process also includes open dialogue. 
Effective public involvement includes notification of proposed actions and activities, effective communication, and appropriate techniques to reach affected communities.

Suggested techniques include:

- Ad hoc task forces

- Advisory committees

- Community events

- Field offices

- Focus groups

- Internet websites

- Newsletters

- Personal contact

- Public meetings

- Questionnaires and surveys

- Workshops

Other techniques are available and should be explored and used as appropriate throughout the assessment. Consideration also should be given to selecting the appropriate staff or other professionals to aid in identifying the right tools or media. The resource section of this document has more information.

\section{Resolving Adverse Impacts}

Throughout the assessment process, transit analysts should seek to address adverse impacts as they are identified. The CIA Reference states that there are four ways to address adverse impacts. These should be considered in order, although opportunities for enhancement should always be sought.

Since the CIA process is iterative, efforts to address one impact may give rise to another adverse impact. Here, again, consideration should be given to addressing impacts in relation to others. The public should participate in the efforts to identify potential adverse impacts and solutions.

The Community Impact Assessment Handbook advises that comments made to address

\section{Resolving Adverse Impacts}

Avoid the impact

Minimize the effects

Mitigate the effects

Enhance the community 
impacts should be documented. This is part of the record of findings whether for NEPA documentation or a standalone summary of the assessment. The documentation also provides a record of the commitments made in the early phases of the assessment and a report on the status of the commitments.

\section{Documenting Findings}

Documentation takes place throughout the assessment process. For some actions, specific documentation is required to comply with Federal or State regulations, e.g. NEPA, the TDP. These regulations provide suggested formats for documentation. In addition, the handbook, and the CIA Reference, provide recommendations on where the CIA information may appear within environmental documentation.

Within the TDP, CIA information may be presented as follows:

- $\quad$ Study Area Base Data (Community Profile).

- Evaluation of Existing Transit Services and the Development of Alternatives.
Other formatting guidelines that may be considered, particularly for stand-alone documents, include:

- $\quad$ an executive summary;

- topics related to the action and as required by legislation;

- a summary of public involvement activities, including substantive comments and findings;

- graphics;

- an objective, unbiased tone;

- conclusions, including concerns, alternatives or solutions, and commitments.

Community impact assessment techniques may be incorporated into transit agencies' decision-making over time. As changes in services are considered or with updates to the TDP, staff should seek opportunities to partner with the affected communities to identify potential impacts, address adverse impacts, and find ways to enhance communities. 


\section{Resources}

The following references and bibliography provide information on other resources to aid in the assessment process.

\section{References Cited}

Corless, James and Luis Arteaga

2000 Pedestrian Safety and Social Justice. In Progress: Surface Transportation Policy Project. Vol. X(1):8.

Federal Highway Administration et alia

1996 Community Impact Assessment: A Quick Reference for Transportation. FHWA-PD-96036. Washington, DC: U.S. Department of Transportation.

Federal Transit Administration, Office of Planning

n.d. The Environmental Process. Electronic document, http:/ / www.fta.dot.gov/office/ planning/ep/index.html. n.d. Social \& Economic Impacts. Electronic document, http://www.fta.dot.gov/office/planning/ ep/ subjarea/se.html.

n.d. Transportation Impacts. Electronic document, http://www.fta.dot.gov/office/planning/ep/ subjarea/trans.html.

Forkenbrock, David J. and Lisa A. Schweitzer 1997 Environmental Justice and Transportation Investment Policy. Iowa City: University of Iowa, Public Policy Center.

Manheim, Marvin L.

1979 Fundamentals of Transportation Systems Analysis, Volume 1 Basic Concepts. Cambridge, MA: Massachusetts Institute of Technology.

Oedel, David G.

2000 The Long March to Transportation Justice in Macon. Progress: Surface Transportation Policy Project X(1):6. 
Office of Enforcement and Compliance Assurance

2000 Environmental Justice: U.S. Environmental Protection Agency. Electronic document. http:/ / es.epa.gov/oeca/main/ej/index.html.

\section{Williams, Kristine A. et alia}

2000 Community Impact Assessment: A Handbook for Transportation Professionals. Electronic docu ment. http://www.cutr.usf.edu/pubs/ cia_handbook.htm.

\section{Bibliography}

Bass, R. and A. Herson

1993 Mastering NEPA: A Step-by-Step Approach. Solano Press.

Bowles, R.T.

1981 Social Impact Assessment in Small Communities. Toronto: Butterworths.
Burchell, R., Listokin, D., et alia

1994 Development Impact Assessment Handbook. Urban Land Institute: Washington, D.C.

Burdge, R.J.

1985 Social Impact Assessment and the Planning Process. Planning \& Public Policy. 11(2), August . 1990 Social Impact Assessment and the Public Involvement Process. Environmental Impact Assessment Review 10(1/2): 81-90.

Branch, K, et al. Guide to Social Assessment. Boulder, CO: Westview Press, 1984.

Burdge, R.J., A Community Guide to Social Impact Assessment, Middleton, WI: Social Ecology Press, 1994.

Canter, L.

1996 Environmental Impact Assessment. Second Edition, New York: McGraw-Hill, Inc.

Canter, L., B. Atkinson, and F.L. Lesitritz, eds. 1985 Impact of Growth: A Guide for Socio-Economic Impact Assessment and Planning. Chelsea MI: Lewis. 


\section{Conner, D.}

1994 The Social Profile. Constructive Citizen Participation.

Council on Environmental Quality

1997 Considering Cumulative Effects Under the National Environmental Policy Act. Washington, DC: Executive Office of the President.

Creighton, J. L.

1981 The Public Involvement Manual. Cambridge: ABT Books.

1992 Involving Citizens in Community Decision Making: A Guidebook. Washington, DC: Program for Community Problem Solving.

\section{Environmental Justice Resource Center}

1996 Proceedings of the National Conference on Environmental Justice and Transportation: Building Model Partnerships. Atlanta: Clarke-Atlanta University.
Federal Transit Administration.

1995 Transportation, Environmental Justice, and Social Equity Conference Proceedings. Prepared by the Surface Transportation Policy Project and Center for Neighborhood Technology. Washington, DC: U.S. Department of Transportation.

1997 Planning, Developing, and Implementing Community-Sensitive Transit. Washington, DC: Office of Planning. October.

Federal Highway Administration and Federal Transit Administration

1994 Innovations in Public Involvement for Transportation Planning. Washington, DC: U.S. Department of Transportation. January .

1996 Public Involvement Techniques for Transportation Decisionmaking. Washington, DC: U.S. Department of Transportation. Summer.

Florida Atlantic University-Florida International University Joint Center for Environmental and Urban Problems

1998 Secondary and Cumulative Impacts of Transportation Projects - Final Report. Prepared for the Florida Department of Transportation. 
Finsterbusch, Kurt

1980 Understanding Social Impact: Assessing the Effects of Public Projects. Beverly Hills, CA: Sage Publications, Inc.

Finsterbusch, Kurt, Lynn Llewellyn, and C.P. Wolf, eds. 1983 Social Impact Assessment Methods. Beverly Hills, CA: Sage Publications, Inc. .

International Association for Impact Assessment n.d. Electronic documents. http:/ / iaia.ext.nodak.edu/ IAI

Interorganizational Committee on Guidelines and Principles for Social Impact Assessment

1994 Guidelines and Principles for Social Impact Assessment. Washington, DC: U.S. Department of Commerce. National Oceanic and Atmospheric Administration.
Louis Berger \& Associates, Inc.

1998 NCHRP Report 403: Guidance for Estimating the Indirect Effects of Proposed Transportation Projects. Washington, DC: National Academy Press.

Mueller, Beth A. et alia

1990 Environmental Factors and the Risk for Childhood Pedestrian-Motor Vehicle Collison Occurrence. American Journal of Epidemiology, 1329( 3):550-560.

National Capital Region Transportation Planning Board. 1996 A System that Serves Everyone: Attracting Non traditional Participants into the Regional Transportation Planning Process. Washington, DC: Metropolitan Washington Council of Governments.

Noyes, P. B.,

1996 Designing the Right Process for Involving the Public. Resource Papers for the 1996 ITE International Conference. 
Program for Community Problem Solving

n.d. Facing Racial and Cultural Conflicts: Tools for Rebuilding Community, Second Edition. Washington, DC: National Civic League.

Skidmore, Owings \& Merrill

1975 Summary of the Environmental Assessment Notebook Series. Prepared for U.S. Department of Transportation DOT P 5600.4. The Notebook Series contains the following individual documents:

Notebook 1: Identification of Transportation Alternatives

Notebook 2: Social Impacts

Notebook 3: Economical Impacts

Notebook 4: Physical Impacts

Notebook 5: Organization and Content of Environmental Assessment Materials

Notebook 6: Environmental Assessment Reference Book

Stoffle, Richard et alia

1981 Establishing Native American Concerns in a Social Impact Assessment. Social Impact Assessment 65-66(4):9.
Transportation Research Board Committee A1D04

2000 Committee on Public Involvement in Transportation. Electronic document. http:// www.ch2m.com/TRB_PI/default.asp.

Transportation Research Board Committee A1F02

2002 Committee on Environmental Analysis in Transportation. Electronic document. http:// www.itre.ncsu.edu/A1F02/default.htm.

U.S. Environmental Protection Agency.

1998 Final Guidance for Incorporating Environmental Justice Concerns in EPA's NEPA Compliance Analysis. Washington, DC: EPA Office of Federal Activities.

U.S. Department of Transportation

1994 Evaluating the Environmental Impacts of Metropolitan Transportation System Plans.

1998 Community Impact Mitigation: Case Studies. Publication No. FHWA-PD-98-024. Washington, DC: Federal Highway Administration: Office of Environment and Planning. May. 
Vanclay, F. and D. Bronstein, eds.

1996 Environmental and Social Impact Assessment. New York, NY: John Wiley \& Sons.

Ward, Beverly G., Ph.D. et alia

2000 Community Impact Assessment. Electronic documents. http:/ / www.ciatrans.net.

2001 Community Impact Assessment in Florida Transportation Projects: Case Studies. Electronic document. http://www.cutr.usf.edu/pubs/CIA in Florida.pdf.
Wilson, Frank \& Associates, Inc.

1994 NCHRP Report 364, Public Outreach Handbook for Departments of Transportation. Washington, D.C. 


\section{Project Team}

\section{FDOT}

Ed Coven, Manager, Public Transit Office

Amy Datz, Project Manager

\section{CUTR}

Beverly G. Ward, Ph.D., Principal Investigator

Kristine M. Williams, AICP, Senior Research Associate

Martin Catalá, Research Associate

Jeffrey Kramer, Research Associate

Jason Winoker, Research Associate

Holly Alderman, Program Assistant

Grace Hunt, Program Assistant

Kimberlee Gabourel, Graduate Research Assistant

Jon Godwin, Graduate Research Assistant

Chrystal Smith, Graduate Research Assistant 


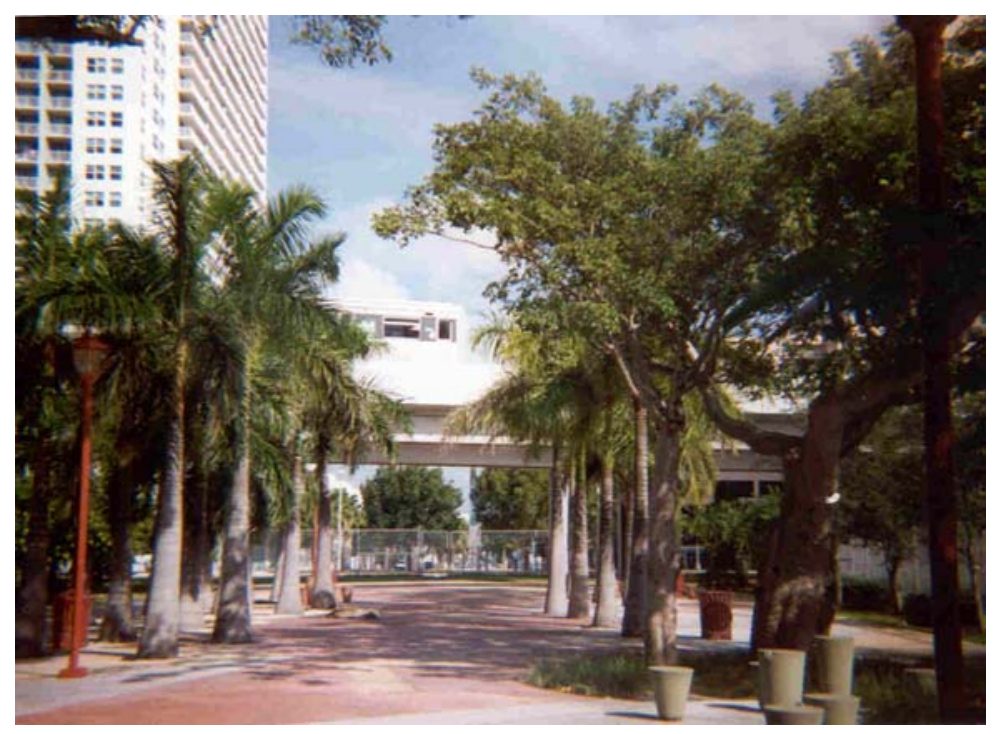

Photographs by Beverly G. Ward

Public Transit Office

Florida Department of Transportation

National Center for Transit Research Center for Urban Transportation Research University of South Florida 